\title{
CD4 cell count and CD4/CD8 ratio increase during rituximab maintenance in Granulomatosis with polyangiitis patients
}

\author{
Emilio Besada ${ }^{\text {Corresp.. }}{ }^{1}$, Johannes C Nossent ${ }^{2,3}$ \\ 1 Bone and Joint Research Group / Institute of Clinical Medicine / Faculty of Health Sciences, UiT The Arctic University of Norway \\ 2 School of Medicine \& Pharmacology QEII Medical Centre Unit, University of Western Australia, Australia \\ 3 Rheumatology, Sir Charles Gairdner Hospital, Nedlands, WA, Australia \\ Corresponding Author: Emilio Besada \\ Email address: emilio.besada@uit.no
}

Introduction: Rituximab (RTX) is a B cell depleting agent approved for the treatment of granulomatosis with polyangiitis (GPA). RTX reduces antibody producing precursor plasma cells and inhibits $B$ and $T$ cells interaction. Infections related to $T$ cell immunodeficiency are not infrequent during RTX treatment. Our study investigated CD4 cell count and CD4/CD8 ratio in GPA patients during the first 2 years of long-term RTX treatment. Methods: Single centre cohort study of 35 patients who received median total cumulative dose of cyclophosphamide (CYC) of $15 \mathrm{~g}$ and were treated with RTX $2 \mathrm{~g}$ followed by retreatment with either $2 \mathrm{~g}$ once annually or $1 \mathrm{~g}$ biannually. Serum levels of total immunoglobulin and lymphocytes subsets were recorded at RTX initiation and at 3, 6, 12, 18 and 24 months. Low CD4 count and inverted CD4/CD8 ratio were defined as CD4 $<0.3$ $x 10^{9} / l$ and ratio $<1$. Results: The CD4 cell count and CD4/CD8 ratio decreased slightly following the initial RTX treatment and then increased gradually during maintenance treatment. While the proportion of patients with low CD4 cell count decreased from $43 \%$ at baseline to $18 \%$ at 24 months, the ratio remained inverted in $40 \%$. Oral daily prednisolone dose at baseline, cyclophosphamide exposure and the maintenance regimen did not influence the CD4 cell count and ratio. Being older $(p=0.012)$ and having a higher $\operatorname{CRP}(p=0.044)$ and ESR $(p=0.024)$ at baseline significantly increased the risk of inverted $\mathrm{CD} 4 / \mathrm{CD} 8$ ratio at 24 months. Inverted ratio at baseline associated with lower total immunoglobulin levels during the study. Conclusions: Overall, CD4 and CD4/CD8 ratio increased during maintenance RTX therapy in GPA with no discernible impact of other immunosuppressive therapy. However the increase in CD4 was not followed by an increase in CD4/CD8 ratio, especially in older patients. Inverted CD4/CD8 ratio associated with lower immunoglobulin levels, suggesting a more profound $B$ cell depleting effect of RTX with a relative increase in CD8+ lymphocytes. 
$1 \mathrm{CD} 4$ cell count and CD4/CD8 ratio increase during rituximab maintenance in Granulomatosis

2 with polyangiitis patients.

3

4 Emilio Besada ${ }^{1}$ and Johannes C Nossent ${ }^{2,3}$

$5{ }^{1}$ Bone and joint research group, Institute of Clinical Medicine, Faculty of Health Sciences, UiT

6 The Arctic University of Norway, 9037 Tromsø, Norway

$7 \quad{ }^{2}$ School of Medicine \& Pharmacology QEII Medical Centre Unit, University of Western

8 Australia, 35 Stirling Highway, Crawley WA 6009, Australia

$9{ }^{3}$ Sir Charles Gairdner Hospital, Rheumatology, Nedlands WA 6009, Australia

11 Email addresses:

12 emilio.besada@,uit.no

13 johannes.nossent@uwa.edu.au

16 Corresponding author:

17 Emilio Besada

18 Bone and Joint Research Group, Department of Clinical Medicine, Faculty of Health Sciences,

19 UiT The Arctic University of Norway, 9037 Tromsø, Norway

20 Telephone: +4777627294

21 Fax: +4777627258

22 E-Mail: emilio.besada@uit.no 


\section{Abstract}

Introduction

27 Rituximab (RTX) is a B cell depleting agent approved for the treatment of granulomatosis with

28 polyangiitis (GPA). RTX reduces antibody producing precursor plasma cells and inhibits B and

29 T cells interaction. Infections related to $\mathrm{T}$ cell immunodeficiency are not infrequent during RTX

30 treatment. Our study investigated CD4 cell count and CD4/CD8 ratio in GPA patients during the

31 first 2 years of long-term RTX treatment.

32 Methods

33 Single centre cohort study of 35 patients who received median total cumulative dose of

34 cyclophosphamide of $15 \mathrm{~g}$ and were treated with RTX $2 \mathrm{~g}$ followed by retreatment with either 2

$35 \mathrm{~g}$ once annually or $1 \mathrm{~g}$ biannually. Serum levels of total immunoglobulin and lymphocytes

36 subsets were recorded at RTX initiation and at 3, 6, 12, 18 and 24 months. Low CD4 count and

37 inverted CD4/CD8 ratio were defined as CD4 $<0.3 \times 10^{9} / 1$ and ratio $<1$.

38 Results

39 The CD4 cell count and CD4/CD8 ratio decreased slightly following the initial RTX treatment

40 and then increased gradually during maintenance treatment. While the proportion of patients

41 with low CD4 cell count decreased from $43 \%$ at baseline to $18 \%$ at 24 months, the ratio

42 remained inverted in $40 \%$. Oral daily prednisolone dose at baseline, cyclophosphamide exposure

43 and the maintenance regimen did not influence the CD4 cell count and ratio. Being older

$44(p=0.012)$ and having a higher CRP $(p=0.044)$ and ESR $(p=0.024)$ at baseline significantly

45 increased the risk of inverted CD4/CD 8 ratio at 24 months. Inverted ratio at baseline associated

46 with lower total immunoglobulin levels during the study.

47 Conclusions 
48 Overall, CD4 and CD4/CD8 ratio increased during maintenance RTX therapy in GPA with no

49 discernible impact of other immunosuppressive therapy. However the increase in CD4 was not

50 followed by an increase in CD4/CD8 ratio, especially in older patients. Inverted CD4/CD8 ratio

51 associated with lower immunoglobulin levels, suggesting a more profound B cell depleting effect

52 of RTX with a relative increase in CD8+ lymphocytes.

53

54

55

56

57

58

59

60

61

62

63

64 


\section{Introduction}

66

67 Granulomatosis with polyangiitis (GPA) is an antineutrophil cytoplasmic antibody (ANCA)-

68 associated vasculitis (AAV) resulting in a necrotizing small to medium vessels vasculitis and a necrotizing granulomatous inflammation involving predominantly the upper and lower respiratory tract and the kidneys. GPA is the result of a complex interplay between the humoral and cellular immunity involving proteinase 3-ANCA (PR3-ANCA), neutrophils, endothelial cells, B and T cells [1].

73 T cells are important in GPA as persistent activation of T cells through aberrant expression of costimulatory molecules favours the expansion of effector memory $\mathrm{T}$ cells and the formation of granuloma [2]. Changes in T cells in GPA patients occur during remission when circulating memory $\mathrm{T}$ cells are increased and naive T CD4+ cells are decreased [3]. Also, T cell-targeted therapies such as abatacept, alemtuzumab and gusperimus are alternative treatments to B cell depletion with rituximab (RTX) in GPA [4].

However, a subgroup of GPA patients has low CD4 cell count and inverted CD4/CD8 ratio

80 irrespective of disease activity and the use of immunosuppressive drugs, possibly due to the recruitment of T cells into the inflamed tissue [5]. It is not clear whether it is the decrease of CD4

82 cell count [6], the expansion of CD8 cell count or a combination of both $[7,8]$ that is responsible 83 for the inversion of the ratio.

85 RTX is a chimeric human-mouse monoclonal antibody directed against CD20 that induces rapid and sustained depletion of premature and mature B cells through antibody-dependent,

87 complement-mediated cellular cytotoxicity and apoptosis [9]. RTX reduces auto-antibody 
88 producing precursor plasma cells, inhibits B cell interaction with auto reactive $\mathrm{T}$ cells and

89 decreases the level of soluble factors secreted by B cells [9]. RTX is approved for the treatment

90 of rheumatoid arthritis (RA) and AAV and is used off label in a large number of autoimmune

91 conditions [10]. In AAV, RTX is used to induce [11,12] and to maintain [13-16] remission

92 through iterative infusions. Relevant side effects of RTX include late onset neutropenia [17],

93 hypogammaglobulinemia $[18,19]$ and an increased risk of infections [16,20-22]. In 2 studies,

$9427-44 \%$ of all severe infections during RTX treatment were either viral or fungal $[16,18]$,

95 possibly related to $\mathrm{T}$ cell immunodeficiency.

96

97 Our study investigated the course of $\mathrm{CD} 4$ cell count, $\mathrm{CD} 4 / \mathrm{CD} 8$ ratio and serum levels of total

98 immunoglobulin (Ig) in GPA patients receiving long-term RTX treatment. 
101

102

103 The Vasculitis Registry in Northern Norway is an observational prospective registry collecting

104 data on disease presentation and course from patients with an established diagnosis of primary

105

106

107

108

109

110

111 At RTX initiation, the patients (median age of 50 (14-79), $54 \%$ males) had median disease

112 duration of 55 months (1-270). $86 \%$ of the patients were ANCA positive; all except one were

113 PR3-ANCA positive. Renal, lung and orbital or/and subglottic involvement was present in $60 \%$,

$11463 \%$ and $57 \%$ of the patients. Median Birmingham Vasculitis Activity Score (BVAS) was 9 (0-

115 22) at baseline. The main indication for RTX was disease relapse ( $80 \%)$, new disease onset (17

$116 \%)$ and maintenance therapy (3\%). Patients had received a median cumulative cyclophosphamide

117 (CYC) dose of $14 \mathrm{~g}(0-250)$ prior to RTX and all had normal total $\operatorname{Ig}$ levels ( $>6 \mathrm{~g} / \mathrm{l})$ prior to

\section{RTX.}

119

120 Patients received $2 \mathrm{~g}$ RTX at induction ( $1 \mathrm{~g}$ twice in a fortnight) with co-administration of

121 methylprednisolone $125 \mathrm{mg}$, paracetamol $1000 \mathrm{mg}$ and either cetirizine $10 \mathrm{mg}$ or polaramine 4

$122 \mathrm{mg}$. RTX was usually combined with a median oral daily prednisolone dose (ODPD) of $20 \mathrm{mg}$

$123(0-60)$ and an immunosuppressive drug in $91 \%$ of the patients. Overall, patients received a 
124 median cumulative RTX dose of $4 \mathrm{~g}$ (2-6) during the first 24 months following its initiation.

125 Respectively $49 \%$ and $40 \%$ received long-term maintenance with the $2 \mathrm{~g}$ annually regimen ( $1 \mathrm{~g}$

126 twice in a fortnight per year) or the $1 \mathrm{~g}$ biannually regimen ( 1 g every 6 months), while $11 \%$

127 received only induction.

128

129 Clinical parameters such as gender, age, erythrocyte sedimentation rate (ESR, nr: $<20$ in men

130 and $<28 \mathrm{~mm} / \mathrm{h}$ in women), C-reactive protein (CRP, $\mathrm{nr}<5 \mathrm{mg} / \mathrm{l}$ ), creatinine (nr: 60-105 in men

131 and 45-90 $\mu \mathrm{mol} / 1$ in women), ANCA titers $(\mathrm{nr}<10 \mathrm{IU} / \mathrm{ml})$, the ODPD and the cumulative dose

132 of CYC were recorded at baseline. Serum levels of total Ig and lymphocytes subsets were

133 measured at RTX initiation and at 3, 6, 12, 18 and 24 months in respectively 35, 24, 31, 34, 31

134 and 34 patients. CD4 and CD8 cell counts were determined by flow cytometry in blood

135 specimens. Normal adult CD4 and CD8 cell counts for our laboratory ranged from $0.3-1.4$ and

$1360.2-0.9 \times 10^{9} / 1$ respectively. Low CD4 cell count was defined as CD4 $<0.3 \times 10^{9} / 1$ and inverted

$137 \mathrm{CD} 4 / \mathrm{CD} 8$ ratio when ratio $<1$. Hypogammaglobulinemia was defined as serum total $\operatorname{Ig}<6 \mathrm{~g} / \mathrm{l}$.

138 Severe infections were defined as infections necessitating intravenous antibiotic treatment and/or

139 hospitalisation.

140

141 Data were analysed with SPSS version 20.0 (SPSS Ltd, Chicago, IL, USA). The results are 142 expressed in percentage for categorical variable and in median (range) for continuous variables,

143 unless specified otherwise. Fisher's exact test, Wilcoxon signed rank test and Man-Whitney U

144 test were used as appropriate. Significant predictors of inversion of the CD4/CD8 ratio at 24

145 months determined during univariable analysis were entered in a multivariable binary logistic 
146 regression model with backward selection ( $\mathrm{p}<0.05$ to enter and $\mathrm{p}<0.10$ to stay). Missing data

147 were excluded from the statistical analyses. P-values $<0.05$ were considered significant. 


\section{3. Results}

150

$1513.1 \mathrm{CD} 4$ cell count and ratio

152 Both the CD4 cell count and the CD4/CD8 ratio decreased initially after RTX administration, 153 and thereafter increased gradually (Figure 1). The CD4 cell count seemed to decrease between

154 baseline and 3 months $\left(0.36\right.$ to $\left.0.28 \times 10^{9} / 1, \mathrm{p}=0.166\right)$, while the ratio decreased significantly from 1551.16 to $0.99(\mathrm{p}=0.011)$. At 24 months, CD4 cell count and ratio had both significantly increased 156 from baseline: respectively $0.45 \times 10^{9} / 1(\mathrm{p}=0.039)$ and $1.38(\mathrm{p}=0.031)$.

157 However, while the proportion of patients with a low CD4 cell count decreased from $43 \%$ at 158 baseline to $18 \%$ at 24 months, the proportion of patients with inverted ratio remained stable 159 around $40 \%$ throughout the study period (Figure 2).

160

1613.2 Baseline clinical profile influence on CD4 cell count and ratio 3.2.1 CD4 cell count and ratio at baseline

163 Patients with low CD4 cell count and inverted ratio at baseline had a tendency to be older 164 (respectively $\mathrm{p}=0.069$ and $\mathrm{p}=0.057$ ) (Tables 1 and 2). Only patients with low CD4 cell count 165 seemed to have a higher cumulative dose of CYC compared with patients with a normal baseline 166 CD4 cell count $(\mathrm{p}=0.071)$ (Table 2$)$.

167 There were no difference in organ involvements, disease duration prior to RTX, BVAS, CRP, 168 ESR, creatinine and ANCA titers at RTX initiation between patients with normal and low CD4 169 cell count at baseline (Table 1) and patients with normal and inverted ratio (Table 2).

$170 \quad 3.2 .2 \mathrm{CD} 4 / \mathrm{CD} 8$ ratio at 24 months 
171 Patients who had an inverted CD4/CD8 ratio at 24 months were older (60 vs. 45 years, $p=0.003$ ),

172 had higher ESR (43 vs. $12 \mathrm{~mm} / \mathrm{hr}, \mathrm{p}=0.009)$ and creatinine $(82 \mathrm{vs} .67 \mu \mathrm{mol} / \mathrm{l}, \mathrm{p}=0.018)$ at

173 baseline. Although not significant, they also had a tendency to higher BVAS (11 vs. 8, p=0.096),

174 CRP (24 vs. $6 \mathrm{mg} / \mathrm{l}, \mathrm{p}=0.076)$ and ANCA titers (16 vs. $5 \mathrm{IU} / \mathrm{ml}, \mathrm{p}=0.089)$. Being older and

175 having higher CRP and ESR at baseline significantly increased the risk of inverted CD4/CD8

176 ratio at 24 months during univariable analysis (Table 3). Age was the most important predictor

177 for inversion of the CD4/CD8 ratio at 24 months during the multivariable analysis (Table 3 ).

178 Being 10 years older at RTX initiation increased the risk by 2.5 times.

179

$180 \quad 3.3$ Serum immunoglobulin levels

181 Serum total immunoglobulin levels in both patients with low CD4 cell count and inverted ratio

182 were lower at all time points during RTX maintenance (Tables 1 and 2). This was only

183 significant in patients with inverted ratio compared with patients with normal ratio at baseline

184 (Table 2). The different RTX maintenance regimens did not influence CD4 cell count, ratio and

185 total immunoglobulin levels in the first 2 years (Table 4).

186

187 3.4 Severe infections in the first 24 months after RTX initiation

188 Two patients $(5.7 \%)$ had severe infections during the study period 3 and 4 months after RTX

189 initiation. One patient had sinusitis secondary to Pseudomonas aeruginosa and the other had

190 Pneumocystis jiroveci pneumonia. They were men, aged 62 and 79 years old, who had received

191250 and $25 \mathrm{~g}$ of CYC. They had low B cell $\left(0.04\right.$ and $\left.0.06 \times 10^{9} / 1\right)$ and CD4 cell counts $(0.17$ and

$\left.1920.26 \times 10^{9} / 1\right)$, inverted ratio (0.35 and 0.43$)$, but had normal serum levels of total $\operatorname{Ig}(11.2$ and 
$19312.6 \mathrm{~g} / \mathrm{l})$ at baseline. At the time of infection, CD4 cell count remained low $(0.16$ and $0.17 \mathrm{x}$

$\left.19410^{9} / 1\right)$ and total Ig had declined by to $4.8 \mathrm{~g} / 1$ and $7.5 \mathrm{~g} / 1$ respectively.

195

1963.5 CD4 cell count and ratio in GPA patients who did not receive RTX maintenance

197 Four GPA patients ( 2 men and 2 women) with a median age of $65(14-79)$ years who had

198 received a cumulative dose of $3(0-25) \mathrm{g}$ of CYC were only administered RTX at induction and

199 did not receive RTX maintenance.

200 The CD4 cell count and ratio decreased from $0.54(0.26-0.98)$ at baseline to $0.36(0.34-0.63) \mathrm{x}$

$20110^{9} / 1$ at 24 months. The CD4/CD8 ratio decreased from baseline and became inverted at 24

202 months: from $1.4(0.43-2.2)$ to $0.61(0.45-2.0)$. 
204

205

206

207

208

209

210

211

212

213

214

215

216

217

218

219

220

221

222

223

224

225

226

\section{Discussion}

In GPA patients on long term RTX treatment, overall CD4 cell count and CD4/CD8 ratio initially decreased in the first 3 months and thereafter gradually increased independent of the ODPD at baseline, the CYC cumulative dose and the maintenance regimen. However in older patients, the inverted ratio at baseline remained unchanged after 2 years and was associated with lower levels of total Ig.

4.1 Early effect of rituximab on CD4 cell count

Prior to RTX treatment, 34 and $43 \%$ of GPA patients had respectively inverted CD4/CD8 ratio and decreased absolute numbers of CD4 cells. Age and the cumulative CYC dose were the most closely associated parameters, although these were not found statistically significant in this small cohort.

During RTX treatment, the early decrease in CD4 cell count seemed dependent of the baseline CD4 count. The higher the CD4 cell count was at baseline, the more CD4 cell count declined at 3 months. GPA patients with normal CD4 cell count (mean $0.67 \times 10^{9} / \mathrm{L}$ at baseline) had a $40 \%$ decrease at 3 months while GPA patients with low CD4 cell count (mean $0.19 \times 10^{9} / \mathrm{L}$ at baseline) had an $89 \%$ increase.

The same pattern was observed in rheumatoid arthritis (RA) [23-25] and in systemic lupus erythematosus (SLE) patients [26], but not in renal transplantation [27]. In RA, CD4 cell count decreased by $37 \%$ at 3 months from a mean of $1.25 \times 10^{9} / 1$ at baseline [23], remained unchanged at 4 months from a mean of $0.93 \times 10^{9} / 1$ at baseline [24] and increased by $14 \%$ from a mean of $0.63 \times 10^{9} / 1$ at baseline during the first 3 months [25]. SLE patients had a $46 \%$ increase in CD4 
227 cell count one month after RTX initiation from a mean of $0.43 \times 10^{9} / 1$ at baseline [26]. However

228 there were no effect of a single dose of RTX $\left(375 \mathrm{mg} / \mathrm{m}^{2}\right)$ on the CD4 and CD8 cell counts as

229 well as the percentage of the different CD4 cell subsets including regulatory T cells at 3 and 24

230 months in renal transplant recipients concomitantly treated with tacrolimus and mycophenolate

231 mofetil during the first 6 months [27].

2334.2 Rituximab failed to normalise the CD4/CD8 ratio at 24 months

234 RTX induction and maintenance failed to normalise the CD4/CD8 ratio in GPA patients with an 235 inverted ratio at baseline, although $\mathrm{CD} 4$ cell counts recovered. Being 10 years older at baseline

236 doubled the risk of inversion of the $\mathrm{CD} 4 / \mathrm{CD} 8$ ratio at 24 months. This suggests a relative

237 increase in CD8+ lymphocytes in older GPA patients receiving RTX. Still it remains unclear

238 how absolute CD4 cell count and ratio related to changes in disease activity, subsets of CD4 and

239 CD8 cells or the combination of toxic drug effects.

240 GPA patients with inverted ratio after 24 months of RTX maintenance seemed to have more

241 disease activity prior to RTX, more kidney involvement and higher inflammation parameters, in

242 accordance to a previous report from Iking-Konert et al [8]. They also had lower serum

243 immunoglobulin during the course of our study, suggesting a more profound B cell depleting

244 effect.

\subsection{Limitations of the study}

247 Our results should be interpreted with caution given the small size of the study cohort and the 248 inherent risk of selection bias. Most of our GPA patients received RTX for refractory and 249 relapsing disease, indicating a selected group who had received high cumulative dose of CYC 
250 and prolonged corticosteroids exposure prior to RTX. In addition, we only followed CD4 and 251 CD8 counts in patients, and did not study important $\mathrm{T}$ cell subsets such as regulatory $\mathrm{T}$ cells. 252 


\section{5. Conclusions}

255

256 Our study suggests that the early decrease in CD4 after induction with RTX seemed dependent

257 of the baseline CD4 count. Overall, CD4 cell count and CD4/CD8 ratio in GPA patients

258 increased over time during RTX with no discernible impact of other immunosuppressive therapy.

259 Increase in CD4 was not always followed by an increase in CD4/CD8 ratio, especially for a

260 subgroup of older patients whom CD4/CD8 ratio remained inverted. Inverted CD4/CD8 ratio

261 associated with lower immunoglobulin levels during maintenance with RTX.

262 Our study suggest that GPA patients with inverted CD4/CD8 ratio seemed to have a more

263 profound B cell depleting effect of RTX and a relative increase in CD8+ lymphocytes. CD4/CD8

264 ratio could be an important marker of a patient's net status of immunodeficiency during RTX,

265 since inverted CD4/CD8 ratio is a common surrogate marker of immunosenescence of impaired

266 responses to vaccination and infections due to the loss of repertoire diversity [28]. 


\section{References}

269

270 1. Kallenberg CG. Pathogenesis of ANCA-associated vasculitides. Ann Rheum Dis.

271

272

273

274

275

276

277

278

279

280

281

282

283

284

285

286

287

288

289 2011;70 Suppl 1:i59-63

2. Wilde B, Thewissen M, Damoiseaux J, van Paassen P, Witzke O, Tervaert JW. T cells in ANCA-associated vasculitis: what can we learn from lesional versus circulating T cells? Arthritis Res Ther. 2010;12:204

3. Abdulahad WH, van der Geld YM, Stegeman CA, Kallenberg CG. Persistent expansion of CD4 effector memory T cells in Wegener's granulomatosis. Kidney Int. 2006;70:93847.

4. Furuta S, Jayne D. Emerging therapies in antineutrophil cytoplasm antibody associated vasculitis. Curr Opin Rheumatol. 2014;26:1-6

5. Berden AE, Kallenberg CG, Savage CO, Yard BA, Abdulahad WH, de Heer E, Bruijn JA, Bajema IM. Cellular immunity in Wegener's granulomatosis: characterizing T lymphocytes. Arthritis Rheum. 2009;60:1578-87

6. Marinaki S, Kälsch AI, Grimminger P, Breedijk A, Birck R, Schmitt WH, Weiss C, van der Woude FK, Yard BA. Persistent T-cell activation and clinical correlations with patients with ANCA-associated vasculitis. Nephrol Dial Transplant. 2006;21:1825-32

7. Ikeda M, Tsuru S, Watanabe Y, Kitahara S, Inouye T. Reduced CD4-CD8 T cell ratios in patients with Wegener's granulomatosis. J Clin Lab Immunol. 1992;38:103-9

8. Iking-Konert C, Vogl T, Prior B, Wagner C, Sander O, Bleck E, Ostendorf B, Schneider M, Andrassy K, Hänsch GM. T lymphocytes in patients with primary vasculitis: 
expansion of CD8+ T cells with the propensity to activate polymorphonuclear

291 neutrophils. Rheumatology. 2008;47:609-16

292 9. Leandro MJ, de la Torre I. Translational mini-review series on B cell-directed therapies:

293 the pathogenic role of B cells in autoantibody-associated autoimmune diseases - lessons

294 from B cell-depletion therapy. Clin Exp Immunol. 2009;157:191-7

295 10. Edwards JCW, Cambridge G. B-cell targeting in rheumatoid arthritis and other auto-

296 immune diseases. Nature Rev Immunol. 2006;6:394-403

297 11. Jones RB, Tevaert JW, Hauser T, Luqmani R, Morgan MD, Peh CA, Savage CO,

298 Segelmark M, Tesar V, van Paassen P, Walsh D, Walsh M, Westman K, Jayne DR;

299 European Vasculitis Study Group. Rituximab versus cyclophosphamide in ANCA-

$300 \quad$ associated renal vasculitis. N Engl J Med. 2010;363:211-20

301 12. Stone JH, Merkel PA, Spiera R, Seo P, Langford CA, Hoffman GS, Kallenberg CG, St

302 Clair EW, Turkiewicz A, Tchao NK, Webber L, Ding L, Sejismundo LP, Mieras K,

303 Weitzenkamp D, Ikle D, Seyfert-Margolis V, Mueller M, Brunetta P, Allen NB, Fervenza

304 FC, Geetha D, Keogh KA, Kissin EY, Monach PA, Peikert T, Stegeman C, Ytterberg SR,

305 Specks U; RAVE-ITN Research Group. Rituximab versus cyclophosphamide for

306 induction of remission in ANCA-associated vasculitis. N Engl J Med. 2010;363:221-32

307 13. Guillevin L, Pagnoux C, Karras A, Khouatra C, Aumaître O, Cohen P, Maurier F,

308 Decaux O, Ninet J, Gobert P, Quémeneur T, Blanchard-Delaunay C, Godmer P, Puéchal

309 X, Carron PL, Hatron PY, Limal N, Hamidou M, Ducret M, Daugas E, Papo T, Bonnotte

310 B, Mahr A, Ravaud P, Mouthon L; French Vasculitis Study Group. Rituximab versus

311 azathioprine for maintenance in ANCA-associated vasculitis. N Engl J Med

312 2014;371:1771-80 
313 14. Smith RM, Jones RB, Guerry MJ, Laurino S, Catapano F, Chaudhry A, Smith KG, Jayne

314 DR. Rituximab for remission maintenance in relapsing ANCA-associated vasculitis.

$315 \quad$ Arthritis Rheum. 2012;64: 3760-69

316 15. Cartin-Ceba R, Golbin JM, Keogh KA, Peikert T, Sánchez-Menéndez M, Ytterberg SR,

317 Fervenza FC, Specks U. Rituximab for remission induction and maintenance in refractory

318 granulomatosis with polyangiitis (Wegener's): ten-year experience at a single center.

$319 \quad$ Arthritis Rheum. 2012;64:3770-8

320 16. Besada E, Koldingsnes W, Nossent JC. Long-term efficacy and safety of pre-emptive

321 maintenance therapy with rituximab in granulomatosis with polyangiitis: results from a

$322 \quad$ single centre. Rheumatology. 2013;52:2041-7

323 17. Besada E, Koldingsnes W, Nossent J. Characteristics of late onset neutropenia in

324 rheumatologic patients treated with rituximab: a case review analysis from a single

325 center. QJM. 2012;105:545-50

326 18. Makatsori M, Kiani-Alikhan S, Manson A, Verma N, Leandro M, Gurugama NP,

327 Longhurst HJ, Grigoriadou S, Buckland M, Kanfer E, Hanson S, Ibrahim MA,

328 Grimbacher B, Chee R, Seneviratne SL. Hypogammaglobulinemia after rituximab

329 treatment- its incidence and outcome. QJM. 2014;107:821-8

330 19. Besada E, Koldingsnes W, Nossent JC. Serum immunoglobulin levels and risk factors for

331 hypogammaglobulinemia during long-term maintenance therapy with Rituximab in

332 patients with Granulomatosis with polyangiitis. Rheumatology. 2014;53:1818-24

333 20. Ram R, Ben-Bassat I, Shpilberg O, Polliack A, Raanani P. The late adverse events of rituximab therapy - rare but there! Leuk Lymphoma. 2009;50:1083-95 
335 21. Sailler L, Attane C, Michenot F, Canonge JM, Rostaing L, Arlet-Suau E, Arlet P, Launay

336 F, Montastruc JL, Lapeyre-Mestre M. Rituximab off-label use for immune diseases:

337 assessing adverse events in a single-centre drug-utilization survey. Br J Clin Pharmacol.

$338 \quad 2008 ; 66: 320-2$

339 22. Gottenberg JE, Ravaud P, Bardin T, Cacoub P, Cantagrel A, Combe B, Dougados M,

340 Flipo RM, Godeau B, Guillevin L, Le Loët X, Hachulla E, Schaeverbeke T, Sibilia J,

341 Baron G, Mariette X; AutoImmunity and Rituximab registry and French Society of

342 Rheumatology. Risk factors for severe infections in patients with rheumatoid arthritis

343 treated with rituximab in the autoimmunity and rituximab registry. Arthritis Rheum.

$344 \quad 2010 ; 62: 2625-32$

345 23. Mélet J, Mulleman D, Goupille P, Ribourtout B, Watier H, Thibault G. Rituximab-

346 induced $\mathrm{T}$ cell depletion in patients with rheumatoid arthritis: association with clinical

347 response. Arthritis Rheum. 2013;65:2783-90

348 24. Thurlings RM, Vos K, Wijbrandts CA, Zwinderman AH, Gerlag DM, Tak PP. Synovial

349 tissue response to rituximab: mechanism of action and identification of biomarkers of

$350 \quad$ response. Ann Rheum Dis. 2008;67:917-25

351 25. Feuchtenberger M, Müller S, Roll P, Waschbisch A, Schäfer A, Kneitz C, Wiendl H,

352 Tony HP. Frequency of regulatory T cells is not affected by transient B cell depletion

353 using anti-CD20 antibodies in rheumatoid arthritis. Open Rheumatol J. 2008;2:81-88

354 26. Sfikakis PP, Boletis JN, Lionaki S, Vigklis V, Fragiadaki KG, Iniotaki A, Moutsopoulos

355 HM. Remission of proliferative lupus nephritis following B cell depletion therapy is

356 preceded by down-regulation of the T cell costimulatory molecule CD40 ligand: an open-

357 label trial. Arthritis Rheum. 2005;52:501-13 
358 27. Kamburova EG, Koenen HJ, van den Hoogen MW, Baas MC, Joosten I, Hilbrands LB.

359 Longitudinal analysis of $\mathrm{T}$ and B cell phenotype and function in renal transplant

360 recipients with or without rituximab induction therapy. PLoS One. 2014;9:e112658

361 28. Blackman MA, Woodland DL. The narrowing of the CD8 T cell repertoire in old age.

$362 \quad$ Curr Opin Immunol. 2011;23:537-42

363

364

365

366 


\section{Figure 1 (on next page)}

CD4 cell count and CD4/CD8 ratio in GPA patients during long-term RTX treatment.

Full line: low CD4 cell count. Dashed line: inverted CD4/CD8 ratio.

Table results are expressed in median and interquartile range. 


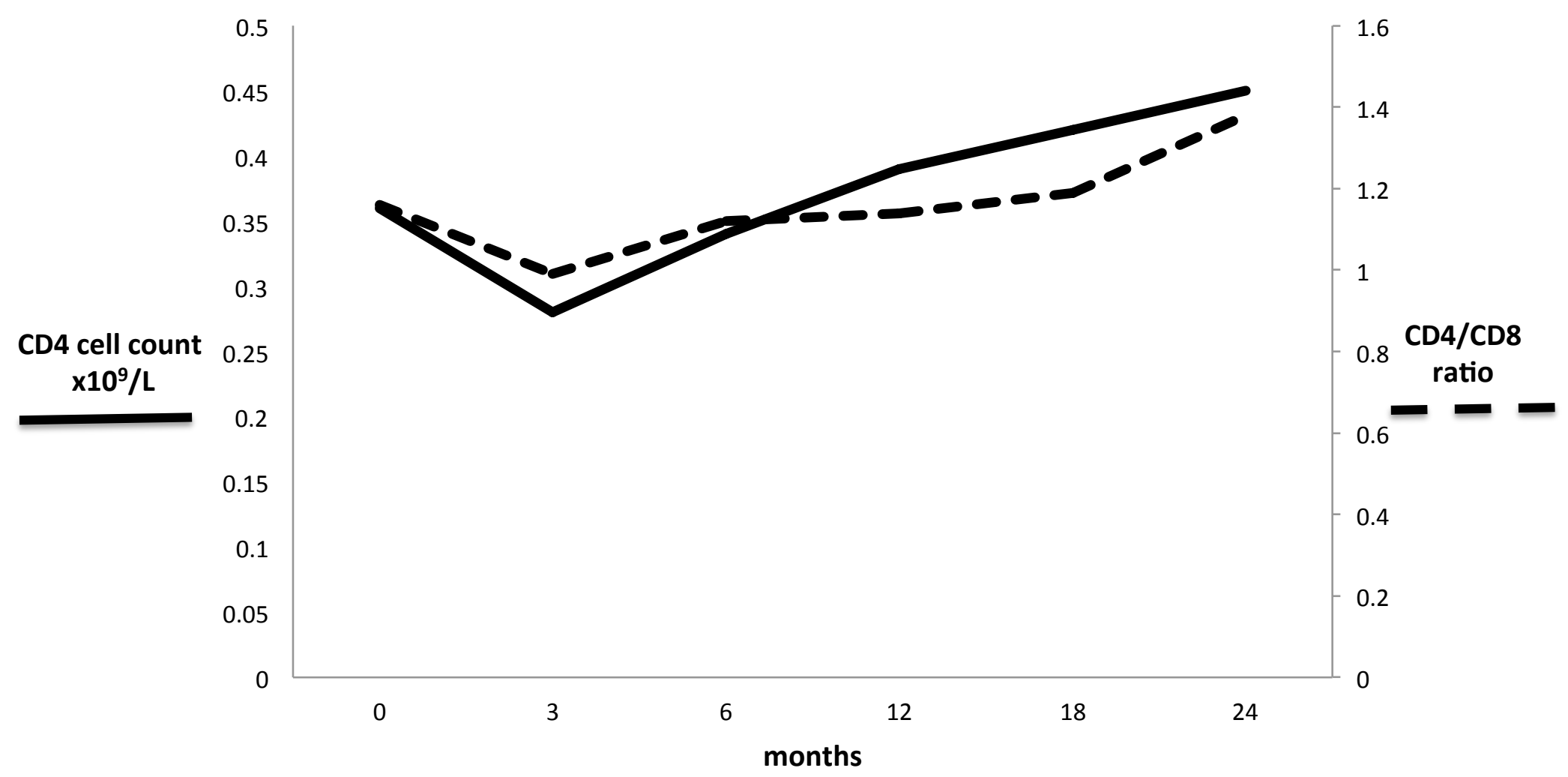

\begin{tabular}{|c|c|c|c|c|c|c|}
\hline $\begin{array}{l}\text { CD4 cell } \\
\text { count } \\
\times 10^{9} / \mathrm{L}\end{array}$ & $\begin{array}{r}0.36 \\
0.22-0.64\end{array}$ & $\begin{array}{r}0.28 \\
0.17-0.50\end{array}$ & $\begin{array}{r}0.34 \\
0.27-0.49\end{array}$ & $\begin{array}{r}0.39 \\
0.29-0.59\end{array}$ & $\begin{array}{r}0.42 \\
0.30-0.56\end{array}$ & $\begin{array}{r}0.45 \\
0.33-0.88\end{array}$ \\
\hline CD4 & 1.16 & 0.99 & 1.12 & 1.14 & 1.19 & 1.38 \\
\hline ratio & $0.85-1.74$ & $0.54-1.34$ & $0.71-1.46$ & $0.75-1.78$ & $0.82-1.85$ & $0.61-1.99$ \\
\hline
\end{tabular}




\section{Figure 2 (on next page)}

Proportion of GPA patients with low CD4 cell count and inverted ratio during long-term rituximab

Full line: low CD4 cell count. Dashed line: inverted CD4/CD8 ratio.

The proportion of patients is expressed in percentage. 
- Inverted CD4/CD8 ratio $\longrightarrow$ Low CD4 cell count

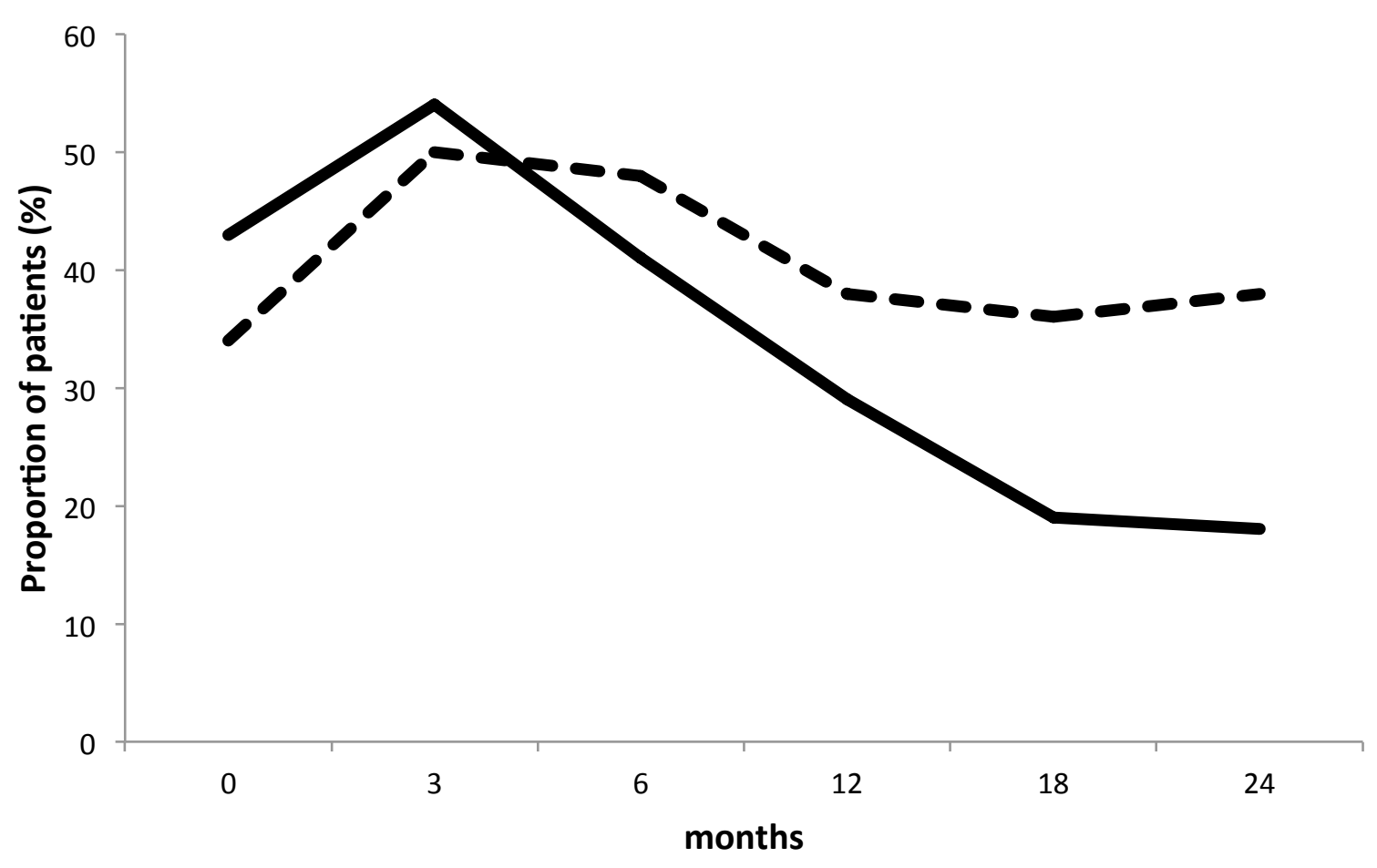




\section{Table $\mathbf{1}$ (on next page)}

Characteristics of GPA patients with low CD4 cell count at baseline against the rest of the cohort.

Results are expressed in number (percentage) for categorical variables and median (range)

for continuous variables. Differences were determined respectively by Fisher's exact test and Mann Whitney $U$ test. Serum total immunoglobulin level and CD4 cell count expressed respectively in $\mathrm{g} / \mathrm{L}$ and $\times 10 \%$ L. ANCA: antineutrophil cytoplasmic antibodies; BVAS:

Birmingham vasculitis activity score; CD: cluster of differentiation; CRP: C-reactive protein; CYC: cyclophosphamide; ESR: erythrocyte sedimentation rate; HypoG:

hypogammaglobulinemia; Ig: immunoglobulins; mo: months; NA: not available; ODPD: oral daily prednisolone dose; RTX: rituximab 


\begin{tabular}{|c|c|c|c|c|}
\hline & & $\begin{array}{r}\text { Low CD4 count } \\
15 \text { patients } \\
\end{array}$ & $\begin{array}{r}\text { Normal CD4 count } \\
20 \text { patients }\end{array}$ & p-value \\
\hline Male & & $9(40 \%)$ & $10(50 \%)$ & 0.784 \\
\hline Age y & & $58(19-79)$ & $47(14-67)$ & 0.069 \\
\hline Disease duration prior RTX mo & & $93(2-270)$ & $45(1-198)$ & 0.254 \\
\hline BVAS at baseline & & $11(4-21)$ & $8.5(0-21)$ & 0.657 \\
\hline ESR mm/t & & $15(3-118)$ & $17(7-100)$ & 0.400 \\
\hline CRP mg/L & & $6(4-135)$ & $7.5(4-127)$ & 0.908 \\
\hline Creatinine $\mu \mathrm{mol} / \mathrm{L}$ & & $75(46-244)$ & $77(43-819)$ & 0.934 \\
\hline ANCA titers IU/L & & $7(0-531)$ & $8(1-109)$ & 0.780 \\
\hline Kidney involvement & & $8(53 \%)$ & $13(65 \%)$ & 0.511 \\
\hline Lung involvement & & $10(67 \%)$ & $12(60 \%)$ & 0.737 \\
\hline Orbital-subglottic involvement & & $10(67 \%)$ & $10(50 \%)$ & 0.492 \\
\hline ODPD mg & & $25(3-50)$ & $20(0-60)$ & 0.458 \\
\hline Total CYC dose $\mathrm{g}$ & & $25(0-250)$ & $13(0-68)$ & 0.071 \\
\hline Total RTX dose g & & $4.0(2-5)$ & $4.0(2-6)$ & 0.780 \\
\hline 1g biannually RTX regimen & & $6(40 \%)$ & $8(40 \%)$ & 1.00 \\
\hline \multirow[t]{4}{*}{ Baseline } & Total Ig & $10.0(8.2-18)$ & $11.8(6.7-21)$ & 0.283 \\
\hline & HypoG & 0 & 0 & NA \\
\hline & CD4 & $0.21(0.06-0.29)$ & $0.61(0.31-1.4)$ & $<\mathbf{0 . 0 0 1}$ \\
\hline & Ratio & $0.94(0.27-2.3)$ & $1.51(0.55-3.0)$ & $<\mathbf{0 . 0 0 1}$ \\
\hline \multirow[t]{4}{*}{ At 3 months } & Total Ig & $7.3(4.8-15)$ & $8.7(6.6-12)$ & 0.247 \\
\hline & HypoG & $3(25 \%)$ & 0 & 0.096 \\
\hline & CD4 & $0.17(0.09-1.4)$ & $0.32(0.17-0.89)$ & 0.064 \\
\hline & Ratio & $0.81(0.34-1.5)$ & $1.12(0.26-2.4)$ & 0.096 \\
\hline \multirow[t]{4}{*}{ At 6 months } & Total Ig & $7.4(4.5-16)$ & $8.4(4.1-12)$ & 0.238 \\
\hline & HypoG & $3(23 \%)$ & $2(11 \%)$ & 0.374 \\
\hline & CD4 & $0.27(0.16-0.57)$ & $0.43(0.24-0.93)$ & $<\mathbf{0 . 0 0 1}$ \\
\hline & Ratio & $0.93(0.38-1.3)$ & $1.25(0.42-4.5)$ & 0.014 \\
\hline \multirow[t]{4}{*}{ At 12 months } & Total Ig & $7.1(4.9-15)$ & $8.5(5.3-15)$ & 0.158 \\
\hline & HypoG & $1(7.1 \%)$ & $2(10 \%)$ & 1.00 \\
\hline & CD4 & $0.29(0.17-0.64)$ & $0.49(0.19-1.4)$ & 0.002 \\
\hline & Ratio & $0.85(0.33-1.8)$ & $1.4(0.51-4.8)$ & 0.010 \\
\hline \multirow[t]{4}{*}{ At 18 months } & Total Ig & $6.7(4.7-17)$ & $7.9(4.9-14)$ & 0.297 \\
\hline & HypoG & $3(21 \%)$ & $1(5.9 \%)$ & 0.304 \\
\hline & CD4 & $0.35(0.13-1.3)$ & $0.49(0.21-1.1)$ & 0.042 \\
\hline & Ratio & $0.92(0.40-1.9)$ & $1.5(0.53-6.0)$ & 0.022 \\
\hline \multirow[t]{4}{*}{ At 24 months } & Total Ig & $6.7(3.0-14)$ & $7.5(4.9-14)$ & 0.179 \\
\hline & HypoG & $5(33 \%)$ & $3(16 \%)$ & 0.417 \\
\hline & CD4 & $0.35(0.06-1.0)$ & $0.70(0.08-1.3)$ & 0.021 \\
\hline & Ratio & $0.84(0.34-2.9)$ & $1.40(0.36-5.4)$ & 0.120 \\
\hline
\end{tabular}




\section{Table 2 (on next page)}

Characteristics of GPA patients with inverted ratio at baseline against the rest of the cohort.

Results are expressed in number (percentage) for categorical variables and median (range)

for continuous variables. Differences were determined respectively by Fisher's exact test and Mann Whitney $U$ test. Serum total immunoglobulin level and CD4 cell count expressed respectively in $\mathrm{g} / \mathrm{l}$ and $\times 10^{\circ} / \mathrm{l}$. ANCA: antineutrophil cytoplasmic antibodies; BVAS:

Birmingham vasculitis activity score; CD: cluster of differentiation; CRP: C-reactive protein; CYC: cyclophosphamide; ESR: erythrocyte sedimentation rate; HypoG:

hypogammaglobulinemia; Ig: immunoglobulins; mo: months; NA: not available; ODPD: oral daily prednisolone dose; RTX: rituximab. 


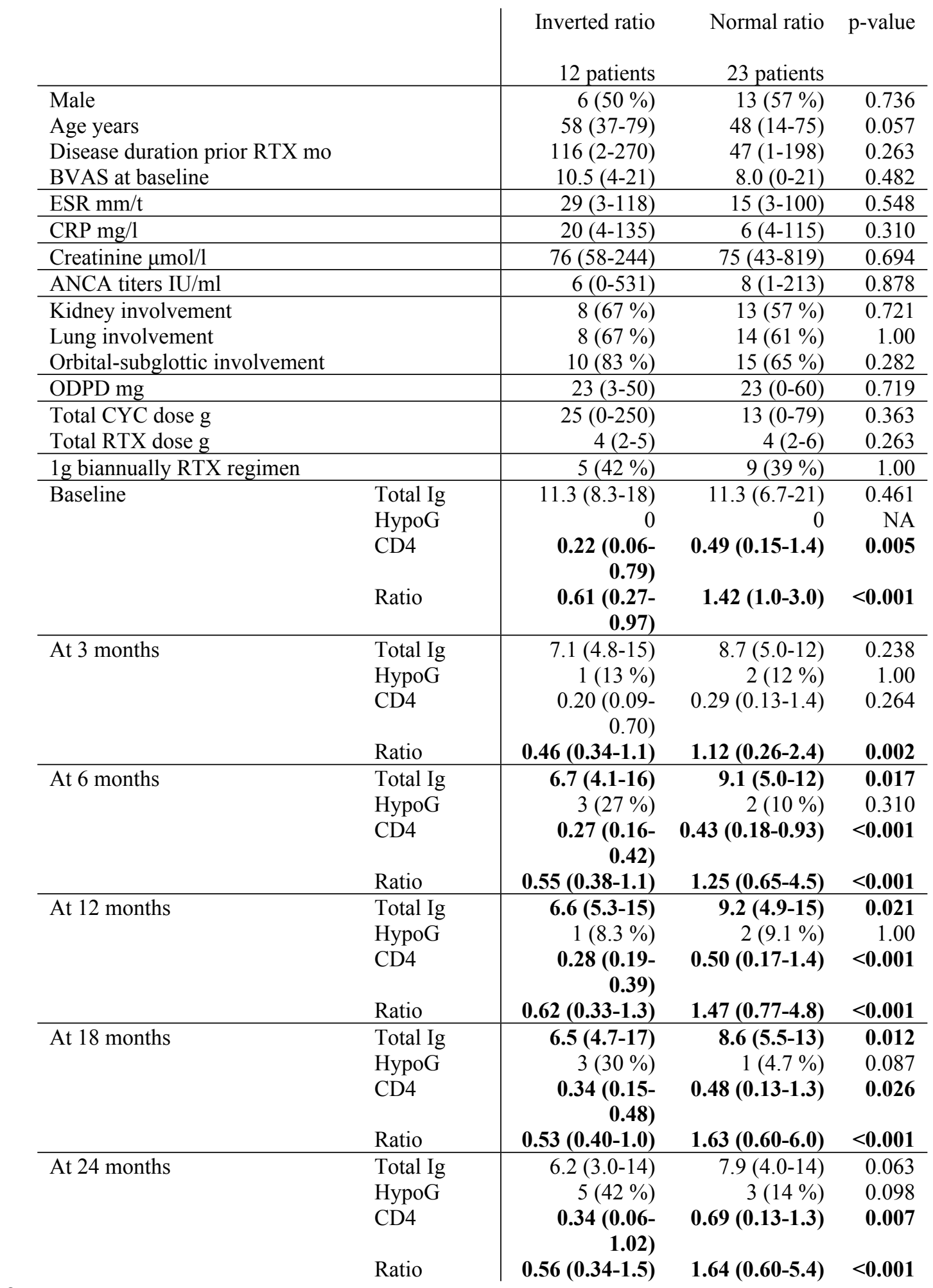




\section{Table 3 (on next page)}

Odds ratio for inverted CD4/CD8 ratio at 24 months in GPA patients receiving rituximab maintenance.

All values were determined at rituximab initiation and were analysed with an unadjusted and multivariable logistic regression models with backward Wald selection (removal if $p<0.10$ ). Significant results are highlighted in bold. ANCA: antineutrophil cytoplasmic antibodies; BVAS: Birmingham vasculitis activity score; $\mathrm{Cl}$ : confidence interval; CRP: C-reactive protein; CYC: cyclophosphamide; ESR: erythrocyte sedimentation rate; Ig: immunoglobulins; mo: months; ODPD: oral daily prednisolone dose; OR: odds ratio; y: years. 


\begin{tabular}{|c|c|c|c|c|c|c|}
\hline & \multicolumn{3}{|c|}{ Unadjusted analysis } & \multicolumn{3}{|c|}{ Multivariable analysis } \\
\hline & OR & $95 \% \mathrm{CI}$ & $\mathrm{p}$-value & OR & $95 \% \mathrm{CI}$ & p-value \\
\hline Men & 1.06 & $0.27-4.24$ & 0.934 & & & \\
\hline Age (y) & 1.10 & $1.02-1.18$ & 0.012 & 1.09 & 1.01-1.18 & 0.027 \\
\hline $\begin{array}{l}\text { Disease } \\
\text { duration (mo) }\end{array}$ & 1.01 & $0.99-1.02$ & 0.075 & 1.01 & $0.99-1.03$ & 0.089 \\
\hline BVAS & 1.13 & $0.96-1.32$ & 0.135 & & & \\
\hline $\operatorname{ESR}(\mathrm{mm} / \mathrm{h})$ & 1.03 & $1.00-1.05$ & 0.024 & 1.03 & $0.99-1.06$ & 0.098 \\
\hline CRP (mg/l) & 1.02 & 1.00-1.04 & 0.044 & & & 0.705 \\
\hline $\begin{array}{l}\text { Creatinine } \\
(\mu \mathrm{mol} / 1)\end{array}$ & 1.02 & $0.99-1.05$ & 0.081 & & & 0.164 \\
\hline $\begin{array}{l}\text { ANCA titers } \\
(\mathrm{IU} / \mathrm{ml})\end{array}$ & 1.03 & $0.98-1.08$ & 0.184 & & & \\
\hline ODPD (mg/d) & 1.04 & $0.98-1.09$ & 0.138 & & & \\
\hline $\begin{array}{l}\text { CYC } \\
\text { cumulative } \\
\text { dose }(\mathrm{g})\end{array}$ & 1.01 & $0.99-1.03$ & 0.388 & & & \\
\hline $\operatorname{IgG}(\mathrm{g} / \mathrm{l})$ & 1.13 & $0.84-1.52$ & 0.428 & & & \\
\hline $\operatorname{IgA}(\mathrm{g} / \mathrm{l})$ & 1.20 & $0.50-2.93$ & 0.682 & & & \\
\hline $\operatorname{IgM}(\mathrm{g} / \mathrm{l})$ & 2.21 & $0.70-7.00$ & 0.177 & & & \\
\hline Total Ig (g/l) & 1.11 & $0.89-1.37$ & 0.357 & & & \\
\hline
\end{tabular}

2 


\section{Table 4 (on next page)}

Characteristics of the GPA patients receiving RTX $1 \mathrm{~g}$ biannually as maintenance treatment compared with the rest of the cohort.

Differences between categorical and continuous variables are determined respectively by Fisher's exact test and Mann Whitney $\mathrm{U}$ test. Serum total immunoglobulin level and CD4 cell count expressed respectively in $\mathrm{g} / \mathrm{L}$ and $\times 10^{\circ} / \mathrm{L}$. CD: cluster of differentiation; CYC:

cyclophosphamide; HypoG: hypogammaglobulinemia; Ig: immunoglobulins; RTX: rituximab. 


\begin{tabular}{ll|rrr} 
& & $\begin{array}{r}\text { 1 g biannually } \\
\text { regimen }\end{array}$ & Other regimens & P-value \\
& & 14 patients & 21 patients & \\
\hline Male & & $9(64 \%)$ & $10(48 \%)$ & 0.491 \\
Age y & & 50 & 47 & 0.702 \\
Total CYC dose g & & 43 & 25 & 0.274 \\
Total RTX dose g & & 4.9 & 3.7 & $<0.001$ \\
\hline Baseline & Total Ig & 12.2 & 10.9 & 0.342 \\
& HypoG & 0 & 0 & NA \\
& CD4 & 0.39 & 0.51 & 0.474 \\
& Ratio & 1.31 & 1.37 & 0.881 \\
\hline At 3 months & Total Ig & 8.4 & 8.6 & 0.426 \\
& HypoG & $3(25 \%)$ & 0 & 0.096 \\
& CD4 & 0.25 & 0.46 & 0.194 \\
& Ratio & 0.80 & 1.11 & 0.123 \\
\hline At 6 months & Total Ig & 8.8 & 7.9 & 0.600 \\
& HypoG & $2(15 \%)$ & $3(16 \%)$ & 1.00 \\
& CD4 & 0.41 & 0.41 & 0.667 \\
& Ratio & 1.51 & 1.20 & 0.421 \\
\hline At 12 months & Total Ig & 8.5 & 8.9 & 0.594 \\
& HypoG & $1(7.7 \%)$ & 1.00 \\
& CD4 & 0.45 & $2(9.5 \%)$ & 0.600 \\
& Ratio & 1.72 & 0.49 & 0.834 \\
\hline At 18 months & Total Ig & 8.3 & 1.32 & 0.666 \\
& HypoG & $4(31 \%)$ & 8.4 & 0.023 \\
& CD4 & 0.37 & 0 & 0.059 \\
& Ratio & 1.78 & 0.57 & 0.953 \\
\hline At 24 months & Total Ig & 7.5 & 1.41 & 0.650 \\
& HypoG & $3(21 \%)$ & 8.2 & 1.00 \\
& CD4 & 0.52 & $5(25 \%)$ & 0.522 \\
& Ratio & 1.91 & 0.61 & 1.42 \\
& & & & 0.823
\end{tabular}

